\title{
INSTRUCTIONAL PROCESS COMPETENCIES: AN ANALYSIS OF CLASSROOM PRACTICES IN WORKERS WELFARE MODEL SCHOOLS
}

\author{
By \\ Tahir Kaleem Siddiqui ${ }^{\bullet}$ \\ Maqsood Alam Bukhari ${ }^{\bullet \bullet}$ \\ Aftab Mughal ${ }^{\circ \bullet \bullet}$
}

\begin{abstract}
This research was designed to study Instructional Process Competencies through observation of classroom practices in workers welfare model schools in Pakistan. The study was designed to identify essential teacher competencies for school effectiveness and to find out if the classroom practices used by Workers Welfare Model School teachers are consistent with these competencies. Forty sample schools were selected from a total of 75 on all Pakistan bases. The data collected through the questionnaire, classroom observations, focused group discussion and official documents was analyzed using both qualitative and quantitative techniques.
\end{abstract}

Most of the teachers' responses and results of observations were consistent in the areas of classroom management and material utilization. The teachers in WWF model schools, though professionally trained, did not use these competencies effectively in the classroom.

The paper recommends that teachers may be provided in-service training on regular basis. The schools at the same time should develop strategies to supervise classroom teaching to ensure that teachers use competencies effectively.

\section{Introduction}

An important role of a teacher is to obtain a positive educational outcome from the students. With this in mind, the teacher is required to possess certain abilities, including, organizing classrooms and managing the behavior or conduct of the students. This, however, does not guarantee effective teaching but does create a suitable environment wherein good teaching becomes possible. Effective teaching does not eliminate classroom behavior problems but does help in reducing them.

A teacher is faced with diverse nature of students, requires adequate knowledge of the community from where the students come and the ability to identify the strengths and individual needs. Technology alone cannot help in achieving these objectives. It can be used as a means to achieve the required objectives and there is a need for acquisition and use of other complimentary competencies.

\footnotetext{
- Ph.D Education (Scholar), Foundation University College of Liberal Arts and Sciences, Rawalpindi

$\bullet$ Principal, Foundation University College of Liberal Arts and Sciences, Rawalpindi.

$\cdots$ Ph.D (Scholar), International Islamic University, Islamabad.
} 
Teachers' competencies may be divided into following two broad categories:

i) Academic Competencies, and

ii) Methodological competencies

\section{Academic Competencies}

Teachers should have knowledge and understanding about the academic aspect. They should have competence in their subjects of teaching and their contribution to the overall education of the child. They should be able to appreciate and understand the changing needs of the society in a scientific age and can understand the psychological bases of education and the factors, which influence education. (Kohll, 1992)

\section{Methodological Competencies of the Teachers}

Teaching methodology is the process of teaching and the resultant learning by developing a link between the students and the knowledge and skill contents embodied in the curriculum. The schools, through effective teaching methods, provide the required environment to the students in learning a particular skill or an area of knowledge. Methodology, as defined by many definitions is a way of doing something in a systematic, orderly and regular manner. Competence on the other hand refers to possessing sufficient skill and knowledge in a particular area. Methodological competencies are thus procedures to undertake a particular work with adequate knowledge and skill.

\section{Lesson planning}

In the classroom, the teacher has greater discretion as to the time devoted to a given lesson. In most high school subjects, the bulk of instruction centers on lecture and discussion. In planning instruction it is important to recognize that teacher behavior and teacher-pupil interaction vary according to the nature of the activity used during instruction (Airasian, 1994).

The teacher can divide the work of the classroom into two areas: The subject matter of lessons, each lesson does have a set amount of content to be put over and the organization of lessons. Teaching/learning is a complex business and there can be talk about individual activities in a lesson, organization of lessons in a course, the syllabus, curriculum, assessment, homework, etc. This aspect of classroom behavior covers all the content and structural sides.

\section{Use of Questions}

Questioning is a key element in the guiding learning process. All students should have equal access to classroom questions and academic interaction. There are two main categories of classroom questioning:

a. Lower-order question is one that can be answered through the processes of memory and recall. For example: "Who was president of the confederacy during the Civil War?" It is a lower-order question. Without consulting outside references, one could respond with the correct answer only by remembering previously learned information. 
b. Higher-order question is one that requires more demanding thought for response. These questions may ask for evaluations, comparisons, causal relationships, problem solving, or divergent, open-ended thinking. Despite the fact that higher-order questions have been shown to produce increased student achievement, most teachers ask very few of them.

\section{Improvement of Student Attitudes}

Sadker and Sadker (1997) explain that changes in student's behavior take place in the following ways:

- The length of student response increases dramatically.

- Students are more likely to support their statements with evidence.

- $\quad$ Speculative thinking increases.

- There are more student questions and fewer failures to respond.

- More students voluntarily participate in discussion.

- There are fewer discipline problems.

- Student achievement increases on written tests that measure more complex levels of thinking.

\section{Classroom Management}

The personality of a teacher coupled with his character is a very important factor in teaching in the classrooms. However, this alone is not sufficient for effective teaching and has to be coupled with competence which is very important relating to the classroom atmosphere. The classroom teaching is affected to a great extent by a number of factors which include the communication style (whether the student understand it or not), the general atmosphere in the class (tense or relaxed), the rules and regulations (strict or relaxed), but in addition to these factors the teacher plays a role by influencing the students' view himself. The teacher has to efficiently manage the class which requires achieving the set objectives /plans for the class with minimum deviations.

\section{Time Management Skill}

The learning in a classroom is an important teaching variable and is a consequence of teaching methodology. It varies significantly from teacher to teacher for the same subject and within similar internal and external environments. The academic learning is a consequence of effective time management in the classroom. The various tasks performed in the classroom are of important consequence; such as, time taken to put the class in order and get started, the lesson plan, and the discussion on issues or question raised by the students. All these have an impact on student's learning and, therefore, require proper attention.

The time wasters have an adverse effect on student's learning in the classroom. Those students who spend more time on pursuing the course contents are able to learn more and resultantly achieve better results. The teachers make classroom time schedules, but it is not enough. What matters: as to how effectively the allocated time is used. An effective use of classroom time and schedule will have a positive effect on scholastic achievement of the students. The positive results of effective time-use has prompted researchers to study it in detail and various terminologies have emerged such as:

- $\quad$ Allocated time 
- $\quad$ Engaged time

- $\quad$ Academic learning time

A teacher who believes in effective classroom time management, will always make a proper plan for the time to be spent in the class. He will avoid late coming since this gives the student time to make noise which takes much time to subside. A good teacher would always tell the rules and regulations to the students to be followed in the classroom along with their expected behavior.

Effective classroom managers always happen to be good planners. They do not enter into room. They wait at the door when the children come in. Starting from the very first day of school, they teach the rules about appropriate student behavior. They do this actively and directly; sometimes they actually model the procedures for getting assistance, leaving the room, going to the pencil sharpener, etc (Sadker and Sadker, 1997).

\section{Development of Self-confidence in Students}

Teaching is one of the most challenging professions. Working with the young people while they develop their personality is a rewarding experience. Teachers help to develop the minds of young people to the end that they can cope with problems affecting our country's future (Gilchrist et al., 1985).

Teaching is not only a noble but one of the most challenging professions. A teacher shapes and develops the personality of young persons to grow up into future leaders on whom the destiny of nations and countries depend. A teacher thus plays a pivotal role in building the future of nations which is a very rewarding experience. Teachers get the opportunity to develop the confidence and personality of their students through various means including subject knowledge and confidence through presentations in the class rooms.

\section{Objectives}

The main objectives of the study were:

a. To observe teaching strategies being practiced in classrooms of WWF schools

b. $\quad$ To judge the classroom management skills of teachers of WWF schools, and

c. To suggest measures for effective classroom teaching.

\section{Methodology}

Population of the study consisted of 75 schools being run by Worker Welfare Fund all over Pakistan. A sample of 25 schools (33.0\% of the total population) from Punjab province was selected randomly. One hundred teachers for seeking their opinion and 40 classrooms (for observation) were selected for the purpose of data collection. Questionnaire and classroom observation checklists were used as data collection tools. The questionnaire was developed on the basis of the key features of instructional process. The basic purpose of using questionnaire was to collect information regarding standards of education taught and practiced. Observation checklist was developed to judge and confirm the use of standards of effective teaching in the classrooms. 
Data collected were analyzed quantitatively as well as qualitatively. Data collected through questionnaire was analyzed at two levels. General Information regarding teachers was analyzed by taking frequency occurrence and percentages at three point scale.

Data collected through questionnaire were tabulated and analyzed through statistical treatment Chi square test $\left(\mathrm{X}^{2}\right)$. The results of which are shown in the following table:

Table -1

Items analysis of instructional process competencies through questionnaire

\begin{tabular}{|l|l|l|l|l|l|}
\hline \multicolumn{1}{|c|}{ Statements } & \multicolumn{1}{|c|}{ A } & \multicolumn{1}{c|}{ UD } & \multicolumn{1}{c|}{ DA } & \multicolumn{1}{c|}{ Total } & \multicolumn{1}{|c|}{$\mathbf{X}^{\mathbf{2}}$} \\
\hline $\begin{array}{l}\text { The teacher applies contemporary knowledge and } \\
\text { new ideas in teaching }\end{array}$ & $\begin{array}{l}36.06 \% \\
(119)\end{array}$ & $\begin{array}{l}6.06 \% \\
(20)\end{array}$ & $\begin{array}{l}57.88 \% \\
(191)\end{array}$ & $\begin{array}{l}100 \% \\
(330)\end{array}$ & 134.02 \\
\hline The teacher uses different questioning techniques & $\begin{array}{l}59.09 \% \\
(195)\end{array}$ & $\begin{array}{l}3.94 \% \\
(13)\end{array}$ & $\begin{array}{l}36.97 \% \\
(122)\end{array}$ & $\begin{array}{l}100 \% \\
(330)\end{array}$ & 152.53 \\
\hline $\begin{array}{l}\text { The teacher manages discipline in his/her class } \\
\text { room. }\end{array}$ & $\begin{array}{l}71.21 \% \\
(235)\end{array}$ & $\begin{array}{l}2.73 \% \\
(9)\end{array}$ & $\begin{array}{l}26.06 \% \\
(86)\end{array}$ & $\begin{array}{l}100 \% \\
(330)\end{array}$ & 240.02 \\
\hline $\begin{array}{l}\text { The teacher uses time management techniques in } \\
\text { teaching }\end{array}$ & $\begin{array}{l}70.91 \% \\
(234)\end{array}$ & $\begin{array}{l}3.03 \% \\
(10)\end{array}$ & $\begin{array}{l}26.06 \% \\
(86)\end{array}$ & $\begin{array}{l}100 \% \\
(330)\end{array}$ & 235.93 \\
\hline The teacher manages classroom activities properly. & $\begin{array}{l}52.73 \% \\
(174)\end{array}$ & $\begin{array}{l}6.67 \% \\
(22)\end{array}$ & $\begin{array}{l}40.61 \% \\
(134)\end{array}$ & $\begin{array}{l}100 \% \\
(330)\end{array}$ & 112.87 \\
\hline $\begin{array}{l}\text { The teacher makes clear statement of objectives of } \\
\text { lesson to students before starting teaching }\end{array}$ & $\begin{array}{l}43.94 \% \\
(145)\end{array}$ & $\begin{array}{l}3.64 \% \\
(12)\end{array}$ & $\begin{array}{l}52.42 \% \\
(173)\end{array}$ & $\begin{array}{l}100 \% \\
(330)\end{array}$ & 134.53 \\
\hline The teacher prepares course contents properly & $\begin{array}{l}56.06 \% \\
(185)\end{array}$ & $\begin{array}{l}3.94 \% \\
(13)\end{array}$ & $\begin{array}{l}40.00 \% \\
(132)\end{array}$ & $\begin{array}{l}100 \% \\
(330)\end{array}$ & 141.07 \\
\hline
\end{tabular}

The data colleted through the classroom observation was analyzed through percentage calculation and presented below in the table 2:

Table -2

Item analysis of instructional process competencies classroom observation

\begin{tabular}{|c|c|c|c|c|}
\hline $\begin{array}{c}\text { Statements } \\
\end{array}$ & Frequently & Sometimes & Never & Total \\
\hline $\begin{array}{l}\text { The teacher applies contemporary } \\
\text { knowledge and new ideas in teaching }\end{array}$ & $\begin{array}{l}10 \% \\
(08)\end{array}$ & $\begin{array}{l}25 \% \\
(20)\end{array}$ & $\begin{array}{l}65 \% \\
(52)\end{array}$ & $\begin{array}{l}100 \% \\
(80)\end{array}$ \\
\hline $\begin{array}{l}\text { The teacher uses different questioning } \\
\text { techniques }\end{array}$ & $\begin{array}{l}6.25 \% \\
(05)\end{array}$ & $\begin{array}{l}18.75 \% \\
(15)\end{array}$ & $\begin{array}{l}75 \% \\
(60)\end{array}$ & $\begin{array}{l}100 \% \\
(80)\end{array}$ \\
\hline $\begin{array}{l}\text { The teacher manages discipline in } \\
\text { his/her class room. }\end{array}$ & $\begin{array}{l}61.25 \% \\
(49)\end{array}$ & $\begin{array}{l}28.75 \% \\
(23)\end{array}$ & $\begin{array}{l}10 \% \\
(08)\end{array}$ & $\begin{array}{l}100 \% \\
(80)\end{array}$ \\
\hline $\begin{array}{l}\text { The teacher uses time management } \\
\text { techniques in teaching }\end{array}$ & $\begin{array}{l}18.75 \% \\
(15)\end{array}$ & $\begin{array}{l}6.25 \% \\
(05)\end{array}$ & $\begin{array}{l}75 \% \\
(60)\end{array}$ & $\begin{array}{l}100 \% \\
(80)\end{array}$ \\
\hline $\begin{array}{l}\text { The teacher manages classroom } \\
\text { activities properly. }\end{array}$ & $\begin{array}{l}11.25 \% \\
(09)\end{array}$ & $\begin{array}{l}66.25 \% \\
(53)\end{array}$ & $\begin{array}{l}22.50 \% \\
(08)\end{array}$ & $\begin{array}{l}100 \% \\
(80)\end{array}$ \\
\hline $\begin{array}{l}\text { The teacher makes clear statement of } \\
\text { objectives of lesson to students before } \\
\text { starting teaching }\end{array}$ & $\begin{array}{l}15 \% \\
(12)\end{array}$ & $\begin{array}{l}10 \% \\
(08)\end{array}$ & $\begin{array}{l}75 \% \\
(60)\end{array}$ & $\begin{array}{l}100 \% \\
(80)\end{array}$ \\
\hline $\begin{array}{l}\text { The teacher prepares course contents } \\
\text { properly }\end{array}$ & $\begin{array}{l}50 \% \\
(40)\end{array}$ & $\begin{array}{l}25 \% \\
(20)\end{array}$ & $\begin{array}{l}25 \% \\
(20)\end{array}$ & $\begin{array}{l}100 \% \\
(80)\end{array}$ \\
\hline
\end{tabular}




\section{Findings and Conclusion}

Findings show that teaching competencies in WWF professionally trained teachers are not fully utilized. The majority of the teachers disagreed that they apply contemporary knowledge and new ideas in teaching. They were also not clear about the statement of objectives of lesson to the students before starting teaching. However, the teachers were managing classroom very effectively. They also used time management techniques and maintained discipline in the classroom. It was observed from the study that teachers were preparing lesson plan properly. This research verified that effective teacher is one who manages the classroom effectively and touches the hearts of the students. There are certain other things which are being identified through this study which are making a teacher outstanding. One of these things is purpose and intention to be a good teacher. It was concluded by the results of both questionnaires and observation that most of the teachers prepared course contents properly, majority of teachers managed discipline in his/her classroom, teachers were following the principles of classroom management effectively. The researcher on the whole concluded that majority of the teachers was well aware of most standards of effective teaching and it was verified through classroom observation that most teachers were not practicing these standards.

\section{Recommendations}

On the basis of findings of the study it is recommended that:

- $\quad$ Theme of school effectiveness in WWF in particular and generally in Pakistani educational system may be revisited.

- What counts for effective education beyond academics achievement like student engagement/participation and community social capital, be considered.

- $\quad$ More serious approaches to meet the value added school need for the society be explored.

- To be good and effective, WWF schools should have a clear organization, characterized by stated goals, values, and standards of performance.

- $\quad$ Training Institute within the WWF School System may be initiated to equip the WWF teachers with new educational technologies and pedagogies.

- It is recommended that the standards for the professional development of the teachers be carefully observed. There is a need to establish pathways to careers through credentials, degrees, and career ladders that are linked to compensation commensurate with experience and qualifications.

- A future research may be conducted on "why most of the teachers do not follow the concepts and standards of school effectiveness in their teaching, despite having knowledge and information about these concepts?"

\section{REFERENCES}

Ainsworth, A. (1976). Teachers talk about in-service education. Journal of Teacher Education, 27, 107-109.

Allwright, R. L. (1990). What do we want teaching materials for? In: R. Rossner and R. Bolitho, (Eds.), Currents in language teaching. Oxford University Press. 
Amahala, B. M. (1979). The Teacher in the Classroom. In: Ukeje, B. O. (Ed) Foundations of Education. Benin-City: Ethiope Publishing. pp. 229-252.

Anderson,W. L, and Ching, M. (1987). Affective Teacher Education. The International Encyclopedia of Teacher Education, Pergamon Press Inc. USA

Anderson, W. L (1991). Increasing Teacher Effectiveness. UNESCO: International Institute for Educational Planning, Paris, P.16, 18.

Arif, H. M. (2003). Human Development and Learning. Majeed Book Depot. Lahore, Pakistan. PP.107-190

Australian Council of Deans of Education (1998). Preparing a Profession. Report of the National Standards and Guidelines for Initial Teacher education Project. Canberra.

Biddle, B., T. Good and J. Brophy (1975). Teachers Make a Difference. New York, Holt Rhinehert and Winston.

Blanchard, K. and S. Johnson. (1982). The one-minute manager. New York: William Morrow.

Caldwell (Ed.), Staff development: A handbook of effective practices (pp. 58-69). Oxford, OH: National Staff Development Council.

Carnine, D. (1976). Effects of two teacher-presentation rates on off-task behaviour, answering correctly, and participation. Journal of Applied Behaviour Analysis, 9(2), 199-206

Casner-Lotton, J. (1988). Expanding the teacher's role: Hammond's school improvement process. Phi Delta Kappan, 69(5), 349-353.

Christle. C.A. and J.W. Schuster. (2003). The effects of using response card on student participation, academic achievement, and on-task behavior during whole-class, math instruction. Journal of Applied Behavior Analysis. 12(3). 147-165.

Crandall, D. (1983). The teacher's role in school improvement. Educational Leadership, 41(3), 6.

Emmer, E.T. and L. M. Stough. (2002). Classroom Management: A critical part of educational psychology, with implications for teacher education. Educational Psychologist, 36(2), $103-112$

Farooq R. A, (1994). Education System in Pakistan. Asia Society for Promotion of Innovation and Reforms in Education, Islamabad, Pakistan.

Farooq, R. A. (1993). Education System in Pakistan: Issues and Problems, Asia Society for Promotion of Innovation and Reform in Education, Islamabad, Pakistan. 
Good, T. (1981). Teacher expectations and student perceptions: A decade of research. Educational Leadership, 38(5), 415-422.

Govt. of Punjab. (1999). Study of the Required Competencies of Elementary Teachers, Secondary Teachers, Teacher Trainers and Development of Programme Evaluation Instruments. Teacher Training Project, Lahore, Pakistan.

Gutek, G. L. (1988). Philosophical and Ideological Perspectives on Education. Englewood Cliffs, N.J. Prentice Hall.

Hall, G. and S. Loucks. (1978). Teacher concerns as a basis for facilitating and personalizing staff development. Teachers College Record, 80 (1), 36-53.

Harris, A. and D. Muijs. (2005). Improving Schools through Teacher Leadership. Berkshire: Open University Press.

Heward, W. L., Gardner, R., III, Cavanaugh, R. A., Courson, F. H., Grossi, T. A., and Barbetta, P. M.(1996). Everyone participates in this class: Using response cards to increase active student response. Teaching Exceptional Children, 28. 4.11.

James, Q. (1989). Effective Secondary Teaching Definition Standards and Trends. Harper and Two Publisher, New York. P.4 Johnson, D., Johnson, R., Holubec, E., and Roy, P. (1984). Circles of learning.

Khalid, T. (1998). Education: an Introduction to Educational Philosophy and History. National Book Foundation, Islamabad, Pakistan. P.4.

Lieberman, A. and L. Miller. (1984). Teachers, their world and their work: Implications for school improvement. Alexandria, VA: Association for Supervision and Curriculum Development.

Ololube, N. P. (2005b). School Effectiveness and Quality Improvement: Quality Teaching in Nigerian Secondary Schools. African Symposium, Vol. 5, No. 4. pp. 17-31.

Siddiqui (2007) Rethinking education in Pakistan.

UNESCO. (2001). Training Personnel for Distance Education. Regional Office for Education in Asia and the Pacific, Bangkok. pp. 27-29.

Yiwen, L. (2004). How Can I Improve the Students' Self-Confidence in our Classroom Activities in Order to Enhance Their Learning?, Experimental Center for Educational Action Research in Foreign Languages Teaching, China, pp-45-50 (NSPP).The Establishment of the National School of Public Policy (Retrieved from http://www.governmentskills.gov.uk/ on 23-09-2009) 